\title{
Õpetajate juhendamispraktika seosed õpilaste kaasatusega õppimisse I ja III kooliastme tundides
}

\author{
Katrin Poom-Valickis ${ }^{\text {a1 }}$, Anna-Liisa Jõgi ${ }^{b}$, \\ Inge Timoštšuk ${ }^{a}$, Annika Oja ${ }^{a}$ \\ a Tallinna Ülikooli haridusteaduste instituut \\ ${ }^{b}$ Tallinna Ülikooli loodus- ja terviseteaduste instituut
}

\begin{abstract}
Annotatsioon
Artiklis keskendutakse õpetajate juhendamispraktika seostele õpilaste kaasatusega õppimisse. Õpetaja poolt tunnis rakendatud juhendamisstiili väljaselgitamisel võeti aluseks isemääramisteooria (self-determination theory), mille kohaselt on õppijate motivatsiooni ja seda väljendavat kaasatust toetava õpikeskkonna loomisel olulised kaks õpikeskkonna dimensiooni: autonoomsuse toetamine ja struktureeritus. Täpsemalt analüüsiti, millist mõju avaldavad õpetajapoolne autonoomsuse toetamine ja struktureeritus põhikooli 2 . klassi $(N=260)$ ja 7. klassi õpilaste $(N=207)$ kaasatusele tunnis. Andmete kogumisel kasutati tunnivaatlust ning küsitleti õpilasi. Uurimistulemuste põhjal võib öelda, et 2. klassi õpilaste hinnangud oma kaasatusele olid 7. klassi õpilaste omadega võrreldes oluliselt kõrgemad ning tüdrukud hindasid mõlemas klassis enda kaasatust kõrgemalt kui poisid. Kaasatuse komponentidest ennustas õpetajapoolne autonoomsuse toetamine 2. klassi õpilaste pingutamist ning 7. klassi õpilaste tunni nautimist. Tunni struktureeritusel oli mõju õpilaste kaasatusele ainult 7. klassis, kus enam struktureeritud tundides olid õpilased keskmiselt tähelepanelikumad ning pingutasid samuti tugevamini.
\end{abstract}

Võtmesõnad: isemääramisteooria, õpetaja juhendamisstiil, autonoomsuse toetamine, struktureeritus, õppijate kaasatus 


\section{Sissejuhatus}

Kõik õpetajad seisavad päevast päeva silmitsi küsimusega, kuidas motiveerida oma õpilasi õppetegevuses aktiivselt osalema ja sellest kasu saama. Põhikooli riikliku õppekava (2010) järgi on õpetaja üks olulisi ülesandeid õppijate õpimotivatsiooni toetamine ja hoidmine. Kooli kontekstis kirjeldatakse mõistega ópimotivatsioon seda, kui palju vaeva ja tähelepanu on õpilased valmis õppeprotsessis eri tegevustele pühendama (Brophy, 2014, lk 14). Õpimotivatsioon avaldub õppetegevustes ja väljendub õppimisse kaasatusena (Skinner \& Pitzer, 2012). Isemääramisteooria ${ }^{2}$ järgi saab sotsiaalne keskkond toetada motivatsiooni ja kaasatust, kui suudab rahuldada inimese autonoomia-, kompetentsus- ja seotusvajaduse, st vajaduse tunda end oma käitumise teadliku algatajana, suutlikuna situatsioonis hästi toime tulla ning seotuna teistega (Ryan \& Deci, 2000, 2002). Kuna klassiruumis on õpetajal täita oluline roll õpimotivatsiooni toetava keskkonna loomisel, siis mõjutab õpetaja käitumismuster õpetamisel, klassi juhtimisel ja õpilastega suhtlemisel ehk tema juhendamisstiil õpilaste motivatsiooni ja seega kaasatust tunnitegevustesse (Jang, Reeve, \& Deci, 2010; Reeve, 2009).

Siinses uurimuses keskendume kahele õpilaste kaasatust oluliselt mõjutavale õpetaja juhendamisstiili aspektile: autonoomsuse toetamisele, mille vastandiks on tugev kontroll, ning struktureeritusele, mille vastandiks on kaos (vt tabel 1). Kui õpetaja toetab õpilaste autonoomsust, st arvestab nende huvide, vajaduste, eelistuste ja isiklike eesmärkidega, pakub neile asjakohaseid õppetegevusi ja optimaalseid väljakutseid, siis suurendab see õpilaste kaasatust õppimisse (Jang et al., 2010). Struktureeritus omakorda aitab luua õpikeskkonna, kus õppijatele on püstitatud üheskoos selged ootused ning pakutakse õppimist toetavat juhendamist ja tagasisidet. Õppeprotsessi struktureeritus on oluline, et õppija saaks keskenduda õppeülesannetele, suudaks oma käitumist reguleerida ning vältida kaose tekkimist ühelt tegevuselt teisele üleminekul (Jang et al., 2010). Seega toetab struktureeritus õpilaste tegutsemistahet, samal ajal kui autonoomsuse toetamine lubab olla ennastjuhtiv (Reeve, 2002).

Eeltoodut arvesse võttes huvitab meid, kuidas on õpetajate juhendamisstiil seotud õpilaste kaasatusega õppimisse. Täpsemalt on eesmärk analüüsida, kuivõrd kasutavad õpetajad põhikooli I ja III kooliastmes õppijate autonoomsust toetavat ja struktureeritud juhendamisstiili ning milline on

2 Self-determination theory eestikeelse vastena on artiklis kasutusel termin isemääramisteooria, mis on enam kooskõlas teooria sisuga ning ka asjaoluga, et teooria autorid kasutavad termini self-determination sünonüümina sageli terminit autonomy (autonoomia), mis viitab iseseisvusele, sõltumatusele, iseotsustamisele või isemääramisele (vt ka Brophy, 2014). 
domineeriva juhendamispraktika mõju õpilaste hinnangul enda kaasatusele tunnis. Meid huvitab ka see, kuivõrd erinevad I ja III kooliastme õpilaste ning poiste ja tüdrukute subjektiivsed hinnangud enda kaasatusele eri juhendamisstiiliga õpetajate tundides.

\section{Autonoomia ja struktureeritus kui õppijate kaasatust toetavad komponendid}

Õpilaste kaasatus viitab aktiivsele osalemisele õppeprotsessis ehk õpilased, kes on tunnitegevustesse kaasatud, on pühendunud ja valmis tulemuste nimel pingutama, osalevad tunnis aktiivselt ning näitavad tegevuste ajal välja positiivseid emotsioone (huvi, entusiasmi, optimismi) (Reeve, 2012; Skinner \& Belmont, 1993). Kaasatus on otseselt seotud õppija akadeemilise edasijõudmise ja tulemustega (Reeve \& Lee, 2014; Reyes, Brackett, Rivers, White, \& Salovey, 2012). Enam kaasatud õpilaste õpitulemused on paremad ja tõenäosus lõpetada õpingud ilma katkestusteta on suurem (Finn \& Zimmer, 2012; Fredricks, Blumenfeld, \& Paris, 2004). Mittekaasatud ópilased on passiivsed, nad ei pinguta ning annavad raskuste puhul kergesti alla, lisaks on neil tihti igav, nad võivad olla kinnised, tõrjuvad või isegi mässumeelsed õpetajate ja klassikaaslaste suhtes (Skinner \& Belmont, 1993). Vähene kaasatus võib peegelduda halvemates õpitulemustes ja koolist välja langemises (Finn \& Zimmer, 2012; Fredricks et al., 2004).

Kaasatus on mitmedimensiooniline konstrukt, mis hõlmab kolme omavahel seotud komponenti: käitumuslikku, kognitiivset ja emotsionaalset kaasatust (Reeve \& Lee, 2014). Käitumuslik kaasatus viitab õppeprotsessis osalemisele, sellele, kuivõrd püüdlik, tähelepanelik ja püsiv õppija on. Kognitiivne kaasatus hõlmab õppimisse investeerimist, tähelepanelikkust ning valmisolekut näha vaeva, et mõista keerulisi ideid ja õppida uusi oskusi. See toetab sügavamate õpistrateegiate kasutamist, samas kui vähese kognitiivse kaasatuse puhul rakendavad õppijad pigem pealiskaudseid õpistrateegiaid ning püüavad ópitut pelgalt meelde jätta (Fredricks et al., 2004; Reeve \& Lee, 2014). Emotsionaalset kaasatust väljendavad õppija afektiivsed reaktsioonid klassiruumis, st huvi, igavus, rõõm, kurbus ja ärevus. Need positiivsed ja negatiivsed reaktsioonid on seotud nii õpetajate, klassikaaslaste, õppimise kui ka kooliga, mõjutades seeläbi kuuluvustunnet ja töötahet (Fredricks et al., 2004; Reyes et al., 2012). Tunni kontekstis võib emotsionaalset kaasatust mõista eelkõige positiivsete emotsioonide avaldumisena õppimisel ning negatiivsete emotsioonide (nt ärevuse) puudumisena (Reeve \& Lee, 2014). 
Isemääramisteooria järgi mõjutab õppija kaasatust see, kuivõrd on indiviidi psühholoogilised põhivajadused autonoomia, kompetentsuse ja seotuse osas rahuldatud. Õpetaja võimuses on luua klassiruumis tingimused, mis kas toetavad õppijate psühholoogilisi vajadusi või vastupidi ignoreerivad neid. Õppijate motivatsioon ja seega kaasatus suurenevad keskkonnas, kus õpetajad leiavad optimaalsed tingimused autonoomsuse (iseseisvusvajaduse) ja struktureerituse (kompetentsusvajaduse) toetamiseks. Seotusvajaduse rahuldamise seisukohalt on omakorda olulised inimestevahelised suhted klassiruumis (Reeve, 2002; Skinner \& Belmont, 1993). Kui õppijad tunnevad, et õpetajad on südamlikud ja hoolivad, siis õpilased on tunnis õnnelikumad ja entusiastlikumad (Rimm-Kaufman, Baroody, Larsen, Curby, \& Abry, 2015; Skinner \& Belmont, 1993). Ka varasemad Eestis tehtud uuringud näitavad, et õpetaja hoolivust väljendavad ja õppijaid toetavad tegevused soodustavad õpilaste paremaid õpitulemusi ning suuremat rahulolu kooliga (Ots, 2014; Tire, 2013). Psühholoogilist ja käitumuslikku kontrolli taotlevad tegevused suurendavad aga rahulolematust (ibid.). Praeguses uurimuses keskendume eelkõige autonoomsuse toetamisele ja struktureeritusele ehk kahele õpetaja juhendamisstiili aspektile, mis täiendavad üksteist (Jang et al., 2010; Reeve, Deci, \& Ryan, 2004) (vt tabel 1).

Tabel 1. Autonoomia ja struktureeritus keskkondlike dimensioonidena (Reeve et al., 2004; Ryan \& Deci, 2002 järgi).

\begin{tabular}{l|l|l}
\hline & $\begin{array}{l}\text { Struktuur } \\
\text { (rohke struktureeritus) }\end{array}$ & $\begin{array}{l}\text { Kaos } \\
\text { (vähene struktureeritus) }\end{array}$ \\
\hline $\begin{array}{l}\text { Autonoomia } \\
\text { (suur vabadus) }\end{array}$ & Autonoomsust toetav keskkond & Lubav keskkond \\
\hline $\begin{array}{l}\text { Kontroll } \\
\text { (väike vabadus) }\end{array}$ & Kontrolliv keskkond & Nõudlik, ebajärjekindel keskkond \\
\hline
\end{tabular}

Õpetaja juhendamisstiil, mis pakub õpilastele suurt vabadust ja autonoomiat, kuid on vähe struktureeritud, loob lubava keskkonna, kus õpilased saavad teha, mida tahavad, neile seatakse vähe piiranguid või ootusi. Seetõttu puuduvad õpilastel vähe huvipakkuvate tegevuste jaoks efektiivsed strateegiad. Eriti vähese autonoomia ja struktureeritusega klassiruumid omakorda võivad olla küll nõudlikud, sisaldades tasusid ja karistusi, kuid neist nõuetest ja sanktsioonidest peetakse kinni ebajärjepidevalt (Reeve et al., 2004). Õpilased tajuvad sellist keskkonda kaootilisena, sest nad ei saa olla kindlad, et õpetaja järgib oma kehtestatud reegleid järjepidevalt ja õiglaselt. Selline õpetaja juhendamisstiil kahjustab õpetajate ja õpilaste suhteid ning pärsib õpilaste motivatsiooni ja kaasatust. 


\section{Õpetaja võimalused autonoomia ja struktureerituse toetamiseks klassiruumis}

Autonoomsuse toetamine ja struktureeritus on positiivselt seotud ning ennustavad õpilaste käitumuslikku kaasatust ja motivatsiooni õppeprotsessis (Jang et al., 2010; Skinner \& Belmont, 1993). Varasemad uuringud on näidanud, et õpilased on motiveeritumad, teevad tunnis rohkem kaasa ja õpivad paremini, kui neile pakutakse valikuvabadust, sõnaõigust ja initsiatiivi struktureeritud moel. Struktureeritus tähendab seda, et õpetajad väljendavad selgeid ootusi õpilaste tulemuste suhtes, juhendavad asjatundlikult ja pakuvad tõhusat tagasisidet (Jang et al., 2010; Koestner, Ryan, Bernieri, \& Holt, 1984; Reeve et al., 2004).

\section{Autonoomsuse toetamine}

Õpetajate tegevused õpilaste iseseisvuse ja kaasatuse toetamisel võib jagada nelja rühma (Jang et al., 2010; Reeve, 2006; Reeve et al., 2004).

1. Sisemiste motivatsiooniallikate eest hoolitsemine. Õpetaja pakutavad õppeülesanded ja tegevused lähtuvad õpilaste huvidest, eelistustest, isiklikest eesmärkidest ja pädevustest. Õppeprotsess pakub võimalust valida ja initsiatiivi üles näidata.

2. Informatiivse, mittekontrolliva keele kasutamine. Klassiruumi reeglitest ja õppimisele seatud ootustest kõneldakse viisil, mis on pigem informatiivne ja paindlik kui kontrolliv ja karm. Informatiivne kõnelemisviis on täpne, võimaldades õpilastele selgitada, miks neil läheb hästi või miks nad on teinud edusamme. Mittekontrolliv kõnelemisviis tähendab, et kõneldes ei suruta õpilastele peale oma arvamust.

3. Õppe sisu väärtuslikkuse selgitamine ja õpilastelt oodatava käitumise põhjendamine. See on oluline, sest klassiruumis paluvad õpetajad tihti teha õpilastel seda, millest õpilased ei ole sisemiselt huvitatud või mis tundub neile vastumeelne. Õpetajad toetavad õpilaste motivatsiooni, kui selgitavad, miks konkreetne tegevus on kasulik, rõhutades tegevuste ja ülesannete praktilisust, väärtust, tähtsust või vajalikkust.

4. Õpilaste negatiivsete tunnete aktsepteerimine. Klassiruumis kehtivad reeglid ja nõudmised on teinekord vastuolus õpilaste eelistustega, samuti tekib konflikte ja seega negatiivseid emotsioone ning vastupanu siis, kui õpetaja soovitud tegevused ei ühti ópilaste enda soovidega. Kui õpetajad aktsepteerivad sellistes situatsioonides negatiivseid tundeid, mitte ei ignoreeri neid ega suru neid alla, siis õpilased tajuvad, et õpetajad mõistavad neid. Autonoomsust toetavad õpetajad aktsepteerivad õpilaste negatiivseid tundeid ning vajaduse korral algatavad 
diskussioone, et aidata õppijatel näha õpitava väärtust. Kontrollivad õpetajad aga reageerivad õpilaste negatiivsetele tunnetele tõrjuvalt, väites, et selline suhtumine ei ole aktsepteeritav ning õpilased peavad muutma oma käitumist (ibid.).

\section{Struktureeritus}

Teine õpetaja juhendamistegevuse aspekt, mis soodustab õpilaste kaasatust tunnitegevustesse, on struktureeritus. Struktureeritus tähendab seda, et õpetajad väljendavad selgeid ootusi õpilaste tegevuse ja tulemuste suhtes. Struktureerituse vastand on kaos, mille puhul õppeprotsess ajab õpilasi segadusse, nt õpetaja jutus esineb vasturääkivusi, puuduvad selged ootused ja juhtnöörid ning nõutakse tulemusi ilma eesmärke seadmata (Jang et al., 2010; Skinner \& Belmont, 1993; Skinner, Wellborn, \& Connell, 1990). Õpetajate hästi struktureeritud käitumist tunnis iseloomustavad järgmised tegevused (Jang et al., 2010).

1. Õpetajad annavad selgeid, täpseid ja detailseid tööjuhiseid, väljendades selgelt ootusi õpilaste käitumise suhtes ja kirjeldades õpilastele mooduseid, kuidas õpitegevustega hakkama saada.

2. Õpetajad juhendavad pidevalt õpilaste tegevust. Kui õpetaja pakub toetavaid ja selgeid juhiseid tunni ajal, siis see õpetab lastele, kuidas pingutada ning püsivalt töötada, et saavutada oma sihte ja õpieesmärke.

3. Struktureeritust toetavad ópetajad annavad konstruktiivset tagasisidet, aidates õpilastel diagnoosida ja täiustada oma oskusi ja võimeid. Sellisel moel saavad õpetajad õpilastele näidata ja aidata neil mõista, mis oskusi tuleb arendada.

Tunni struktureeritus on oluline, sest see aitab suurendada õppija kontrolli oma tulemuste üle ning toetab piiride seadmist ja tunnis stabiilse õpikeskkonna loomist (Jang et al., 2010; Skinner \& Belmont, 1993).

\section{Eesmärk ja hüpoteesid}

Praegune uuring on üks osa projektist „Eesti põhikooliõpilaste koduse õpikoormuse uuring"', mille eesmärk oli selgitada välja Eesti põhikooliõpilaste kooliväline õpikoormus ning analüüsida võimalusi selle vähendamiseks või muutmiseks nii, et see toetaks parimal viisil õpilase arengut. Motivatsioon ja valmisolek koduste töödega tegeleda luuakse tunnis ning seega analüüsiti selle uuringu raames ka õpetaja õpetamistegevusi. Nende

3 Vt http://oppekava.innove.ee/eesti-pohikooliopilaste-koduse-opikoormuse-uuring-2013-2015/. 
tegevuste väljaselgitamisel lähtuti isemääramisteooriast, milles nähakse motivatsiooni ja kaasatust mõjutavate teguritena autonoomsuse toetamist ja struktureeritust (vt Reeve, 2002).

Artiklis keskendume ópetajate juhendamispraktika seostele õpilaste kaasatusega õppimisse. Täpsemalt on eesmärk analüüsida, kuivõrd kasutavad põhikooli I ja III kooliastme õpetajad õppijate autonoomsust toetavat ja struktureeritud juhendamisstiili ning milline on domineeriva juhendamispraktika mõju õpilaste kaasatusele tunnis. Varasemate uurimuste põhjal eeldasime, et õpetajapoolne autonoomsuse toetamine ja struktureeritus ennustavad õpilaste kaasatust õppeprotsessi (Jang et al., 2010; Timoštšuk \& Jaanila, 2015). Samuti huvitas meid, kuivõrd erinevad I ja III kooliastme õpilaste ning poiste ja tüdrukute subjektiivsed hinnangud enda kaasatuse kohta. Toetudes varasematele uurimustele, eeldasime siinkohal, et tüdrukud on tunnitegevustesse rohkem kaasatud kui poisid (Rimm-Kaufman et al., 2015).

Meie teada on Eestis õpetaja juhendamispraktikat isemääramisteooria alusel vähe uuritud, seega loovad saadavad kogemused ja teadmised hea baasi edasisteks uuringuteks ning uurimisinstrumentide edasiarendamiseks.

\section{Metoodika}

\section{Valim}

Uurimuse valimisse kuuluvad „Eesti põhikooliõpilaste koduse õpikoormuse uuringus” osalenud 8 üldhariduskooli 2. ja 7. klassi õpilased. Uuringus osalenud koolide seas oli nii linna- kui ka maakoole. 2. klassis vaadeldi kõiki 11 klassi ühe õppepäeva tunde, milles osales kokku 260 õpilast (sh 134 poissi, 124 tüdrukut ja kaks õpilast, kelle sugu ei ole teada). 7. klassi valimisse kuulus 10 klassi, kelle tunde vaadeldi ühe koolipäeva jooksul. Kokku osales neis tundides 207 õpilast 7. klassist (sh 100 poissi ja 107 tüdrukut). Uuringust võtsid osa vaid need lapsed, kelle vanemad ei olnud lapse osalemisest keeldunud.

\section{Protseduur}

Uurimisküsimustele vastuste leidmiseks vaadeldi õpetajate tunnitegevusi ja küsitleti õpilasi. Kokku vaadeldi 2. klassis 41 tundi, mida juhendas 19 õpetajat. 7. klassis vaadeldi 50 tundi, mida juhendas 41 õpetajat. Igat tundi vaatles kaks vaatlejat. Vaatlejad olid teadlikud vaatluse eesmärgist ning läbinud lühikese koolituse, mille üks osa oli videotunni vaatlus uuringus 
kasutatavate vaatluslehtede alusel. Õpetajad ei olnud teadlikud, mida täpselt vaadeldakse, ning vaatlejad liikusid koos klassidega, st vaadeldi samade õpilaste eri tunde ühe koolipäeva jooksul. Vaatlejad jälgisid õpetaja juhendamistegevust tunnis, tegid märkmeid ning hindasid tunni lõpus autonoomsuse toetamist ja struktureeritust vaatluslehtedel toodud skaalade alusel. Lisaks paluti iga tunni lõpus õpilastel hinnata enda kaasatust konkreetses tunnis.

\section{Mõõtevahendid}

Õpetajate tegevuste hindamiseks kasutati vaatluslehti ja õpilaste hinnangute väljaselgitamiseks küsimustikku. Vaatluslehtede ja küsimustiku koostamisel võeti aluseks Jangi ja tema kolleegide (2010) uuringu instrumendid, mida praeguse uuringu korraldajad kohandasid Eesti oludele.

\section{Autonoomsuse toetamine ja struktureeritus klassiruumis}

Õpetajate tegevuse vaatluslehed sisaldasid kolme väidet bipolaarsel skaalal nii tunni autonoomsuse toetamise kui ka struktureerituse kohta. Iga väidet hinnati seitsmepallisel Likerti skaalal. Skaala otspunktide kirjeldused, mille abil hinnati, kuidas toetab õpetaja autonoomsust tunnis, olid järgmised: a) välistele versus sisemistele motivatsiooniallikatele toetumine; b) kontrolliv versus informatiivne keel ja c) õpilaste negatiivse suhtumise muutmine/ignoreerimine versus õpilaste negatiivse suhtumise teadvustamine ja aktsepteerimine (Jang et al., 2010).

Bipolaarsed kirjeldused tunni struktureerituse hindamisel olid järgmised: a) tunni sissejuhatuses puuduv, ebaselge, mitmeti mõistetav ja segadusse ajav tööjuhend versus selge, arusaadav, konkreetne, detailne tööjuhend; b) tunni ajal nõrk versus tugev juhendamine ja c) puuduv või mitmeti mõistetav versus oskusi arendav ja õpetlik tagasiside tunnis (Jang et al., 2010).

Kahe vaatleja hinnangute kokkulangevust hinnati vaatlejate hinnangute korrelatsiooniga (intraclass correlation - ICC), mille tõlgendamisel lähtuti Cicchetti (1994) toodud jaotusest: ICC $<0,40$ - nõrk; 0,40-0,59 - keskmine; $0,60-0,74$ - hea; $0,75-1,00$ - suurepärane. Autonoomsuse toetamise skaala väidete ICC oli vahemikus $0,73-0,79$, struktureerituse ICC oli vahemikus $0,60-0,66$. 


\section{Õpilaste kaasatus}

Keskmiselt osales ühes tunnis 21 õpilast. Enne iga tunni algust palusid vaatlejad, et õpetajad jätaksid paar minutit aega tunni lõpust, et õpilased saaksid täita küsimustiku, mis koosnes neljast väitest õpilase kaasatuse kohta tunnitegevusse. Tunni lõpus tutvustas üks vaatlejatest õpilastele küsimustikku ning neil paluti hinnata enda kaasatust konkreetses tunnis järgmiste väidete alusel: „Selles tunnis olin ma tähelepanelik”, „Selles tunnis töötasin ma hoolega kaasa”, „Selles tunnis püüdsin nii palju pingutada, kui suutsin" ja "Selles tunnis nautisin kaasatöötamist" (Jang et al., 2010). Fredricksi ja tema kolleegide (2004) kaasatuse kolmekomponendilise mudeli järgi hõlmavad esimesed kaks väidet käitumuslikku, kolmas kognitiivset ja neljas emotsionaalset aspekti. Õpilastel paluti hinnata enda kaasatust tunnis viiepallisel Likerti skaalal: 1 - ei vasta üldse tõele, 2 - pigem ei vasta tõele, 3 - osaliselt vastab / ei vasta tõele, 4 - pigem vastab tõele, 5 - vastab täielikult tõele.

\section{Andmeanalüïs}

Andmeid analüüsiti statistikapaketiga SPSS 18.0. Kahetasandilise regressioonimudeli hindamiseks kasutati statistikapaketti MPlus 6.0 (Muthén \& Muthén, 1998-2010). Regressioonimudelis oli esimeseks tasandiks määratud õpilane ning teiseks tasandiks ainetund, millest õpilased osa võtsid.

Regressioonimudelis oli õpilase tasandi tunnusena määratud õpilase sugu ning tunni tasandi tunnusena vaatlusandmed õpetajapoolse autonoomsuse toetamise ja struktureerituse kohta. Õpilase tasandil ennustas sugu kõiki nelja kaasatuse väidet. Tunni tasandil ennustasid autonoomsuse toetamise ja struktureerituse skaalade keskmised kõigi selles tunnis osalenud õpilaste nelja kaasatuse väite latentseid tunnuseid. Andmete vastavust hüpoteesina püstitatud regressioonimudelile hinnati $\chi^{2}$-testiga. Kuna mõlema klassi esialgsed mudelid ei olnud identifitseeritud (vabadusastmete arv $=0$ ) ja seetõttu ei olnud võimalik hinnata andmete vastavust mudelile, siis fikseeriti $\chi^{2}$-testi jaoks mõlemas mudelis üks statistiliselt ebaoluline regressioon nulliks. 2. klassi mudelis fikseeriti nulliks struktuur ennustamas nautimist tunni tasandil ja 7. klassi mudelis sugu ennustamas nautimist õpilase tasandil. 


\section{Tulemused}

Andmete kirjeldavad statistikud ja omavahelised seosed on toodud tabelites 2 ja 3. Nii 2. kui ka 7. klassis olid kõik kaasatuse komponendid omavahel tugevas positiivses seoses. Samuti olid positiivselt seotud mõlema klassi tundides vaadeldud õpetajapoolne autonoomsuse toetamine ja struktureeritus.

Hinnangud enda tähelepanelikkusele, hoolega kaasatöötamisele, pingutamisele ja tunni nautimisele olid 2. klassi õpilastel oluliselt kõrgemad võrreldes 7. klassi õpilastega ( $t$-test, $p<0,001$ kõigi kaasatuse komponentide puhul).

Tabel 2. Õpilaste kaasatuse väidete keskmised $(M)$, standardhälbed (SD), minimaalsed (min) ja maksimaalsed (max) väärtused ning omavahelised korrelatsioonid

\begin{tabular}{l|c|c|c|c|c|c|c}
\hline 2. klass & $M$ & $S D$ & Min & Max & 1 & 2 & 3 \\
\hline 1. Tähelepanelikkus & 4,52 & 0,86 & 1 & 5 & - & & \\
\hline 2. Kaasatöötamine & 4,56 & 0,76 & 1 & 5 & 0,54 & - & \\
\hline 3. Pingutamine & 4,36 & 1,05 & 1 & 5 & 0,42 & 0,46 & - \\
\hline 4. Nautimine & 4,29 & 1,19 & 1 & 5 & 0,51 & 0,48 & 0,52 \\
\hline 7. klass & & & & & & & \\
\hline 1. Tähelepanelikkus & 4,13 & 0,93 & 1 & 5 & - & & \\
\hline 2. Kaasatöötamine & 4,07 & 0,97 & 1 & 5 & 0,71 & - & \\
\hline 3. Pingutamine & 3,88 & 1,12 & 1 & 5 & 0,62 & 0,71 & - \\
\hline 4. Nautimine & 3,64 & 1,25 & 1 & 5 & 0,53 & 0,58 & 0,54 \\
\hline
\end{tabular}

Märkus. Kõik korrelatsioonid on statistiliselt olulised tasemel $p<0,001$.

Tabel 3. Autonoomsuse toetamise ja struktureerituse keskmised $(M)$, standardhälbed (SD), minimaalsed ( $\min$ ) ja maksimaalsed (max) väärtused ning omavahelised korrelatsioonid vaadeldud tundides

\begin{tabular}{l|c|c|c|c|c}
\hline 2. klass & $M$ & $S D$ & Min & Max & 1 \\
\hline 1. Autonoomsuse toetamine & 4,52 & 0,86 & 1,67 & 7 & - \\
\hline 2. Struktureeritus & 4,56 & 0,76 & 3,67 & 7 & 0,54 \\
\hline 7. klass & & & & & \\
\hline 1. Autonoomsuse toetamine & 4,13 & 0,93 & 1,5 & 7 & - \\
\hline 2. Struktureeritus & 3,64 & 1,25 & 2,33 & 7 & 0,53 \\
\hline
\end{tabular}

Märkus. Kõik korrelatsioonid on statistiliselt olulised tasemel $p<0,001$. 
Kahetasandiline regressioonimudel vastas 2 . klassi andmetele $\left(\chi^{2}=0,18\right.$, $d f=1, p=0,676, \mathrm{CFI}=1,00, \mathrm{RMSEA}=0,00)$. Regressioonianalüüs näitas, et 2. klassis on tüdrukud endi hinnangul kaasatud tunni tegevustesse rohkem kui poisid (vt joonis 1 ). Nad on tähelepanelikumad $(\beta=0,14, p=0,003)$, töötavad rohkem kaasa $(\beta=0,15, p<0,001)$, pingutavad enam $(\beta=0,16$, $p<0,001)$ ning ka naudivad tundi enam $(\beta=0,13, p=0,006)$. Õpetajapoolne autonoomsuse toetamine ennustas tunni tasandil seda, kuivõrd õpilased keskmiselt tunnis pingutavad. Tundides, kus õpetaja toetas enam õpilaste autonoomsust, pingutasid õpilased endi sõnul rohkem $(\beta=0,39$, $p=0,03)$.

2. klass
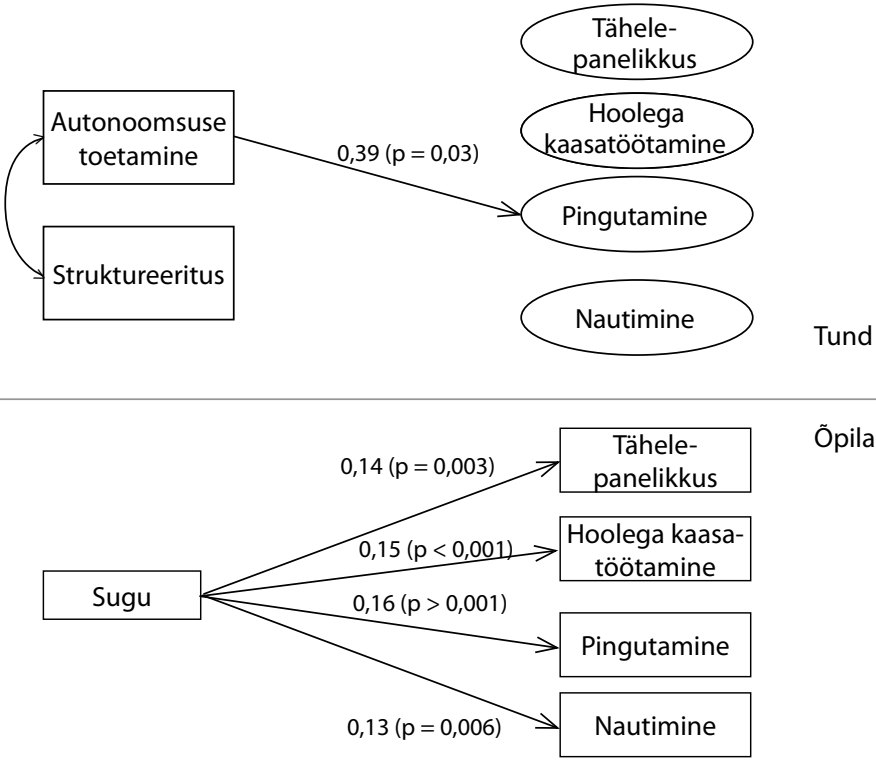

Õpilane

Joonis 1. 2. klassi kahetasandiline regressioonimudel. Joonisel ei kajastu kaasatuse jääkvariatiivsuste vahelised korrelatsioonid. Sugu on kodeeritud järgmiselt: 1 = poiss, 2 = tüdruk

Ka 7. klassi andmed vastasid hüpoteesina püstitatud regressioonimudelile $\left(\chi^{2}=0,39, d f=1, p=0,533, \mathrm{CFI}=1,00, \mathrm{RMSEA}=0,00\right)$. Samamoodi nagu 2. klassis, olid ka 7. klassis tüdrukud tundides tähelepanelikumad $(\beta=0,11$, $p=0,001)$, töötasid enam kaasa $(\beta=0,12, p<0,001)$ ja pingutasid roh$\operatorname{kem}(\beta=0,10, p<0,001)$ kui poisid (vt joonis 2$)$. Selles, kuivõrd õpilased tundi nautisid, tüdrukute ja poiste vahel erinevust ei leitud. Õpetajapoolne autonoomsuse toetamine 7 . klassi tundides ennustas positiivselt seda, kuivõrd tunnis osalevad õpilased keskmiselt tunnist rõõmu tundsid $(\beta=0,43$, 
$p=0,022)$. Paremini struktureeritud tundides olid õpilased tähelepanelikumad $(\beta=0,38, p=0,086)$ ning pingutasid rohkem $(\beta=0,31, p=0,089)$.

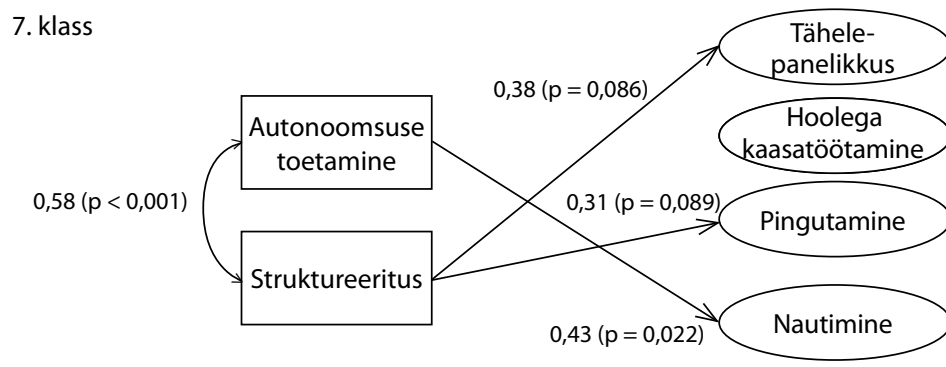

Tund

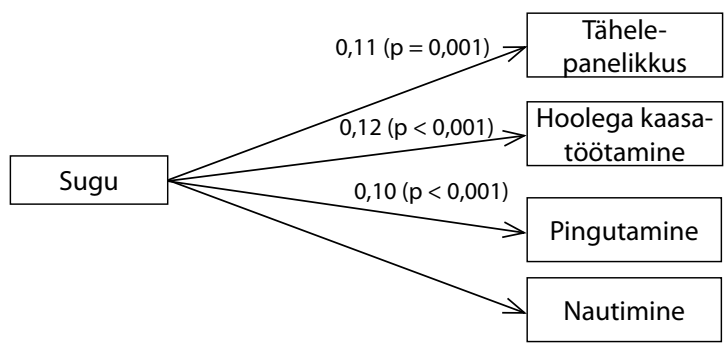

Õpilane

Joonis 2. 7. klassi kahetasandiline regressioonimudel. Joonisel ei kajastu kaasatuse jääkvariatiivsuste vahelised korrelatsioonid. Sugu on kodeeritud järgmiselt: $1=$ poiss, 2 = tüdruk

\section{Arutelu}

Töös uurisime, kuivõrd kasutavad õpetajad õppijate autonoomsust toetavat ja struktureeritud juhendamisstiili ning milline on domineeriva juhendamispraktika mõju põhikooli 2. ja 7. klassi õpilaste kaasatusele tunnis. Vaadeldud tundide põhjal võib öelda, et uuringus osalenud õpetajate tunnid pakuvad õpilastele autonoomsust ja struktureeritust mõõdukalt. 2. klassi õpetajad rakendavad 7. klassi õpetajatega võrreldes keskmiselt enam autonoomsust toetavat ja struktureeritud juhendamisstiili. Samas varieeruvad eri õpetajate juhendamisstiilid oluliselt, seda eriti autonoomsuse toetamise poolest.

Nii nagu varasemates uuringutes, selgus ka praegusel juhul, et õpetajad, kes toetavad õppijate autonoomsust, struktureerivad oma tunde tõhusamalt (vt tabel 3). Positiivne korrelatsioon juhendamisstiili kahe komponendi vahel oli oodatav, sest mõlemad toetavad õppijakeskset õpetamist, soodustades õppijate iseseisvust ning pakkudes õppeprotsessis juhendamist ja 
õppimist toetavat tõhusat tagasisidet (Reeve, 2006; Sierens, Vansteenkiste, Goossens, Soenens, \& Dochy, 2009).

Toetudes eelnevatele uuringutele, eeldasime, et ópetajapoolne autonoomsuse toetamine ja struktureeritus ennustavad ópilaste kaasatust õppeprotsessis (Jang et al., 2010). Ilmnes, et üldiselt on 2. klassi õpilased enam tunnitegevustesse kaasatud kui 7. klassi õpilased - nad andsid kõrgemad hinnangud kõigile kaasatuse komponentidele (vt tabel 2). 2. klassi õpilaste kaasatust võib positiivselt mõjutada peale teiste tegurite ka klassiõpetajate keskmiselt suurem autonoomsuse toetus ja struktureeritus võrreldes 7. klassi õpetajatega (vt tabel 3). Analüüsides eraldi õpetaja juhendamisstiili kahe komponendi mõju õppijate kaasatusele, selgus, et õpetajapoolne autonoomsuse toetamine ennustas tunni tasandil 2. klassis seda, kuivõrd õpilased keskmiselt tunnis pingutavad (vt joonis 1), ning 7. klassis seda, kuivõrd tunnis osalevad õpilased keskmiselt tunnist rõõmu tundsid (vt joonis 2). Samas tunni struktureeritusega ilmnesid positiivsed seosed vaid 7. klassi õpilaste puhul, sest paremini struktureeritud tundides olid õpilased tähelepanelikumad ning pingutasid rohkem. Ka varem on leitud, et struktureeritus ennustab õpilaste kollektiivset käitumuslikku kaasatust (Jang et al., 2010; Tucker et al., 2002), aga õpilaste enda hinnatud subjektiivset arvamust kaasatuse kohta see ei ennusta. Samamoodi nagu õpetajate juhendamisstiil, oli ka õpilaste kaasatuse variatiivsus klassi sees suur ning seega võib oletada, et peale autonoomsuse toetamise mõjutavad õpilase motivatsiooni ja aktiivset osavõttu tunnis ka individuaalsed tegurid, mis ei ole otseselt seotud klassi sotsiaalse keskkonnaga. Objektiivsema tulemuse saamiseks tuleks edaspidi õpilaste kaasatuse uurimisel kasutada mitmekesisemaid meetodeid (nt enesehinnangule lisaks vaatlust ja õpetaja hinnangut).

Analüüsides poiste ja tüdrukute subjektiivseid hinnanguid oma kaasatusele vaadeldud tundides, leidis kinnitust meie oletus, et tüdrukud on tundidesse rohkem kaasatud kui poisid. Ka PISA 2012 uuring näitas, et kuigi enamik Eesti õpilastest nõustub, et tugev pingutamine koolis aitab saada heasse ülikooli ja leida hea töö ning head hinded on olulised, ehk pingutatakse eelkõige välise motivatsiooni ajel, hindavad pingutamist koolis kõige kõrgemalt just eesti õppekeelega koolide tüdrukud (Tire, 2013). Nimelt andsid 2. klassi tüdrukud kõrgemad hinnangud enda kaasatusele tunnitegevustesse kõigis kaasatuse komponentides: nad on enda hinnangul tunnis tähelepanelikumad, töötavad rohkem kaasa, pingutavad enam ning ka naudivad tundi enam kui poisid. 7. klassi tüdrukud on endi hinnangul tundides tähelepanelikumad, töötavad enam kaasa ja pingutavad rohkem kui poisid. See tulemus on sarnane teiste varasemate uuringute omaga, kus 
samuti selgus, et tüdrukud on suuremal määral kaasatud tunnitegevustesse kui poisid (Lietaert, De Fraine, Verschueren, \& Laevers, 2014; Marks, 2000; Rimm-Kaufman et al., 2015). Samas õpirõõmu ehk tunni nautimise poolest uuringus osalenud põhikooli III astme 7. klassis tüdrukute ja poiste vahel erinevusi enam ei ilmne. Ka hindavad nii 2. kui ka 7. klassi õpilased seda kaasatuse komponenti võrreldes teiste komponentidega madalamalt. Seega on õppijad tähelepanelikud, töötavad üldiselt kaasa ja pingutavad tunnis, kuid naudivad vähem õppeprotsessi ning tunnevad sellest vähem rõõmu. Ka varasemad III kooliastmes tehtud uuringud kinnitavad, et kuigi Eesti õpilased saavutavad häid õpitulemusi, tunnevad nad vähest koolirõõmu (Ruus et al., 2007), ning Eesti õpilaste õnnelikkuse näitaja koolis jääb alla teiste OECD riikide keskmisele (Tire, 2013).

\section{Kokkuvõte}

Isemääramisteooria järgi soodustab motivatsiooni ja õppimisse kaasatust selline õpikeskkond, mis võimaldab inimesel rahuldada oma psühholoogilisi vajadusi kompetentsuse, seotuse ja autonoomia järele. Neist ükskõik millise vajaduse rahuldamine aitab kaasa inimese motiveeritud olemisele, kuid ainult autonoomsusvajaduse rahuldamine võimaldab tunda end ennastmääratlevana (Deci \& Ryan, 1985; Ryan \& Deci, 2002) ning on ülioluline iseseisvate ja ennastjuhtivate õppijate kujundamisel. Samas peegeldub uuringu tulemustest see, et õpetajad toetavad tunnitegevustes õpilaste autonoomsust pigem mõõdukalt ning eri tundides on suur varieeruvus autonoomsuse toetamises. Ka TALIS 2013 uuringust ilmnes, et Eesti õpetajatele on iseloomulik tugev juhendamine ja väiksem autonoomsuse toetamine ehk ollakse enam suunatud õppetulemuste kontrollile ning aktiveerivat praktikat ja õppe diferentseerimist kasutatakse tagasihoidlikult (Übius, Kall, Loogma, \& Ümarik, 2014). Arvestades Eesti õpetajate keskmist vanust, mis on olenevalt piirkonnast 45-48 aastat (Ots, Vaher, Selliov, \& Laanoja, 2008), on võimalik, et nõukogude aega jäänud isiklik koolikogemus ja õpetajakoolitus mõjutavad õpetajakesksema käsitlusviisi domineerimist. Näiteks ilmnes võrdlevast uuringust, milles analüüsiti, kuidas USA ja Venemaa lapsevanemad ja nende õpetajad toetavad autonoomsust ning kuidas see on seotud teismeliste heaolu ja akadeemilise motivatsiooniga, et Venemaa noored tajuvad nii enda õpetajaid kui ka vanemaid oluliselt kontrollivamatena kui USA noored (Chirkov \& Ryan, 2001). Seega n-ö kontrollivas ühiskonnas kipuvad ka vanemad ja õpetajad kasutama kontrollivat, mitte õppija autonoomsust toetavat juhendamisstiili. Samas rõhutatakse (Reeve, 2009; Ryan \& Deci, 2002), et ka mehhanismid, 
millega õpetajaid hinnatakse ja kontrollitakse, mõjutavad nende käitumist. Kui hea õpetaja mõõdupuuks on pelgalt head testi- ja eksamitulemused, siis kalduvad õpetajad kasutama ka enam kontrollivat juhendamisstiili. Samuti mõjutavad õpetaja käitumist lapsevanemate ootused - nimelt peavad lapsevanemad tihti heaks õpetajaks just ranget ja kontrollivat õpetajat. Positiivne on aga see, et autonoomsust toetav juhendamisstiil on õpitav (Aelterman, Vansteenkiste, Van den Berghe, De Meyer, \& Haerens, 2014; Reeve et al., 2004). Õpilaste kaasatus suurenes märgatavalt peale seda, kui nende õpetajad olid läbinud kursuse, kuidas toetada sisemist motivatsiooni, kasutada informatiivset keelt, põhjendada ja selgitada esitatavaid nõudeid, tunnustada ning aktsepteerida negatiivseid tundeid (Reeve et al., 2004). Seega tuleks õpetajakoolituses ja täiendõppes enam tähelepanu pöörata õpetaja juhendamisstiili analüüsile ja arendamisele.

Praegusel uuringul on ka mitmed piirangud, mida tuleks edaspidi arvesse võtta. Esiteks oli valim suhteliselt väike. Teiseks pidid õpilased kirjutama küsimustikule oma nime ning seetõttu võisid nad vastata sotsiaalselt soovitud viisil. Samuti kasutati õpilaste kaasatuse hindamiseks ainult õpilaste enda hinnanguid ja vaid nelja väidet. Tulevastes uuringutes oleks oluline suurendada valimit, korrata mõõtmisi eri koolipäevadel ning täpsustada ja mitmekesistada instrumente, millega ópilaste kaasatust hinnata. Peale kaasatuse võiks paluda õpilastel hinnata ka seda, mil määral nad tajuvad tundides autonoomsuse toetamist ja struktureeritust. Samuti oleks oluline andmete analüüsimisel arvestada õpilaste motivatsiooni variatiivsusega, sest õpilaste sisemine motivatsioon ja huvi eri ainete ja tegevuste vastu on erinev, seega on ka õpetaja tegevuste mõju õpimotivatsiooniga seotud käitumisele tõenäoliselt erinev. Lisaks võiks uurida, kas õpilaste kaasatus tunnitegevustesse on seotud teiste teguritega, näiteks õppesisu, -materjalide või õppija endaga. Ka tuleks õpetajaid vaadelda rohkem kui ühel korral ning uurida pikema aja jooksul, missugused on seosed õpetaja juhendamisstiili ja õpilaste kaasatuse vahel. Praeguses uuringus kasutati õpetaja juhendamisstiili hindamisel ainult ühte mõõteinstrumenti. Edaspidi võiks vaatlusele lisaks kasutada küsimustikku, kus õpetajad peaksid oma juhendamisstiili ise hindama.

\section{Kasutatud kirjandus}

Aelterman, N., Vansteenkiste, M., Van den Berghe, L., De Meyer, J., \& Haerens, L. (2014). Fostering a need-supportive teaching style: Intervention effects on physical education teachers' beliefs and teaching behaviors. Journal of Sport \& Exercise Psychology, 36(6), 595-609. doi: http://dx.doi.org/10.1123/jsep.2013-0229 
Brophy, J. (2014). Kuidas õpilasi motiveerida: Käsiraamat õpetajatele. Tallinn: SA Archimedes.

Chirkov, V. I., \& Ryan, R. M. (2001). Parent and teacher autonomy-support in Russian and U.S. adolescents: Common effects on well-being and academic motivation. Journal of Cross-Cultural Psychology, 32(5), 618-635. doi: http://dx.doi.org/10.1177/0022022101032005006

Cicchetti, D. V. (1994). Guidelines, criteria, and rules of thumb for evaluating normed and standardized assessment instruments in psychology. Psychological Assessment, 6(4), 284-290. doi: http://dx.doi.org/10.1037/1040-3590.6.4.284

Deci, E. L., \& Ryan, R. M. (1985). The general causality orientations scale: Selfdetermination in personality. Journal of Research in Personality, 19(2), 109-134. doi: http://dx.doi.org/10.1016/0092-6566(85)90023-6

Finn, J. D., \& Zimmer, K. S. (2012). Student engagement: What is it? Why does it matter? In S. L. Christenson, A. L. Reschly, \& C. Wylie (Eds.), Handbook of research on student engagement (pp. 21-44). New York: Springer Science \& Business Media. doi: http://dx.doi.org/10.1007/978-1-4614-2018-7_5

Fredricks, J. A., Blumenfeld, P. C., \& Paris, A. H. (2004). School engagement: Potential of the concept, state of the evidence. Review of Educational Research, 74(1), 59-109. doi: http://dx.doi.org/10.3102/00346543074001059

Jang, H., Reeve, J., \& Deci, E. L. (2010). Engaging students in learning activities: It is not autonomy support or structure but autonomy support and structure. Journal of Educational Psychology, 102(3), 588-600. doi: http://dx.doi.org/10.1037/a0019682

Koestner, R., Ryan, R. M., Bernieri, F. J., \& Holt, K. D. (1984). Setting limits on children's behavior: The differential effects of controlling versus informational styles on intrinsic motivation and creativity. Journal of Personality, 54(3), 233248. doi: http://dx.doi.org/10.1111/j.1467-6494.1984.tb00879.x

Lietaert, S., De Fraine, B., Verschueren, K., \& Laevers, F. (2014). The role of teacher support for the gender gap in students' behavioral engagement. International Congress for School Effectiveness and Improvement (ICSEI). Yogyakarta, Indonesia.

Marks, H. M. (2000). Student engagement in instructional activity: Patterns in the elementary, middle, and high school years. American Educational Research Journal, 37(1), 153-184. doi: http://dx.doi.org/10.3102/00028312037001153

Muthén, L. K., \& Muthén, B. O. (1998-2010). Mplus user's guide (6th ed.). Los Angeles, CA: Muthén \& Muthén.

Ots, A. (2014). Õpilaste heaolu resilientsus ja mõistestruktuuri areng: erinevused kooliga rahulolu säilitamisel ebameeldivate koolikogemuste ja klassiõpetaja kasvatusstiili taustal. Eesti Haridusteaduste Ajakiri, 2(1), 132-161. doi: http://dx.doi.org/10.12697/eha.2014.2.1.06

Ots, A., Vaher, K., Selliov, R., \& Laanoja, P. (2008). Ülevaade Eesti õpetajaskonnast. Külastatud aadressil http://www.hm.ee/index.php?popup=download\&id=8781.

Põhikooli riiklik õppekava (2010). Riigi Teataja I, 29.08.2014, 20. Külastatud aadressil https://www.riigiteataja.ee/akt/129082014020.

Reeve, J. (2002). Self-determination theory applied to educational settings. In E. L. Deci \& R. M. Ryan (Eds.), Handbook of self-determination research (pp. 183203). Rochester, NY: The University of Rochester Press. 
Reeve, J. (2006). Teachers as facilitators: What autonomy-supportive teachers do and why their students benefit. Elementary School Journal, 106(3), 225-236.

doi: http://dx.doi.org/10.1086/501484

Reeve, J. (2009). Why teachers adopt a controlling motivating style toward students and how they can become more autonomy supportive. Educational Psychologist, 44(3), 159-175. doi: http://dx.doi.org/10.1080/00461520903028990

Reeve, J. (2012). A self-determination theory perspective on student engagement. In S. L. Christenson, A. L. Reschly, \& C. Wylie (Eds.), Handbook of research on student engagement (pp. 149-172). New York: Springer Science \& Business Media. doi: http://dx.doi.org/10.1007/978-1-4614-2018-7_7

Reeve, J., Deci, E. L., \& Ryan, R. M. (2004). Self-determination theory: A dialectical framework for understanding socio-cultural influences on student motivation. In D. M. McInerney \& S. Van Etten (Eds.), Big theories revisited (pp. 31-60). Greenwich, CT: Information Age Press.

Reeve, J., \& Lee, W. (2014). Students' classroom engagement produces longitudinal changes in classroom motivation. Journal of Educational Psychology, 106(2), 527540. doi: http://dx.doi.org/10.1037/a0034934

Reyes, C. R., Brackett, M. A., Rivers, S. E., White, M., \& Salovey, P. (2012). Classroom emotional climate, student engagement, and academic achievement. Journal of Educational Psychology, 104(3), 700-712.

doi: http://dx.doi.org/10.1037/a0027268

Rimm-Kaufman, S. E., Baroody, A. E., Larsen, R. A. A., Curby, T. W., \& Abry, T. (2015). To what extent do teacher-student interaction quality and student gender contribute to fifth graders' engagement in mathematics learning? Journal of Educational Psychology, 107(1), 170-185. doi: http://dx.doi.org/10.1037/a0037252

Ruus, V-R., Veisson, M., Leino, M., Ots, L., Pallas, L., Sarv, E-S., \& Veisson, A. (2007). Õpilaste edukus, toimetulek ja heaolu koolis. M. Veisson \& V-R. Ruus (koost.), Eesti kool 21. sajandi algul. Kool kui arengukeskkond ja õpilaste toimetulek (lk 17-58). Tallinn: Tallinna Ülikooli Kirjastus.

Ryan, R. M., \& Deci, E. L. (2000). Self-determination theory and the facilitation of intrinsic motivation, social development, and well-being. American Psychologist, 55(1), 68-78. doi: http://dx.doi.org/10.1037/0003-066X.55.1.68

Ryan, R. M., \& Deci, E. L. (2002). Overview of self-determination theory: An organismic-dialectical perspective. In E. L. Deci \& R. M. Ryan (Eds.), Handbook of self-determination research (pp. 3-33). Rochester, NY: The University of Rochester Press.

Sierens, E., Vansteenkiste, M., Goossens, L., Soenens, B., \& Dochy, R. (2009). The synergistic relationship of perceived autonomy support and structure in the prediction of self-regulated learning. The British Journal of Educational Psychology, 79(1), 57-68. doi: http://dx.doi.org/10.1348/000709908X304398

Skinner, E. A., \& Belmont, M. J. (1993). Motivation in the classroom: Reciprocal effects of teacher behavior and student engagement across the school year. Journal of Educational Psychology, 85(4), 571-581.

doi: http://dx.doi.org/10.1037/0022-0663.85.4.571

Skinner, E. A., \& Pitzer, J. R. (2012). Developmental dynamics of student engagement, doping, and everyday resilience. In S. L. Christenson, A. L. Reschly, \& 
C. Wylie (Eds.), Handbook of research on student engagement (pp. 21-44). New York: Springer Science \& Business Media.

doi: http://dx.doi.org/10.1007/978-1-4614-2018-7_2

Skinner, E. A., Wellborn, J. G., \& Connell, J. P. (1990). What it takes to do well in school and whether I've got it: A process model of perceived control and children's engagement and achievement in school. Journal of Educational Psychology, 82(1), 22-32. doi: http://dx.doi.org/10.1037/0022-0663.82.1.22

Timoštšuk, I., \& Jaanila, S. (2015). Primary teachers' instructional behavior as related to students' engagement in science learning. Procedia - Social and Behavioral Sciences, 197, 1597-1602.

doi: http://dx.doi.org/10.1016/j.sbspro.2015.07.117

Tire, G. (toim.) (2013). PISA 2012 Eesti tulemused. Eesti 15-aastaste oppilaste teadmised ja oskused matemaatikas, funktsionaalses lugemises ja loodusteadustes. Tallinn: SA Innove.

Külastatud aadressil www.hm.ee/index.php?popup=download\&id=12473.

Tucker, C. M., Zayco, R. A., Herman, K. C., Reinke, W. M., Trujillo, M., Carraway, K., ... Ivery, P. D. (2002). Teacher and child variables as predictors of academic engagement among low-income African American children. Psychology in the Schools, 39(4), 477-488. doi: http://dx.doi.org/10.1002/pits.10038

Übius, Ü., Kall, K., Loogma, K., \& Ümarik, M. (2014). Rahvusvaheline vaade õpetamisele ja óppimisele. OECD rahvusvahelise õpetamise ja õppimise uuringu TALIS 2013 tulemused. Tallinn: SA Innove. Külastatud aadressil https://www.hm.ee/sites/default/files/talis2013_eesti_raport.pdf. 


\title{
Associations between teachers' instructional practices and student engagement in the 2nd and 7th grade classrooms
}

\author{
Katrin Poom-Valickis ${ }^{a 1}$, Anna-Liisa Jõgi ${ }^{b}$, \\ Inge Timoštšuk ${ }^{a}$, Annika Oja ${ }^{a}$ \\ a School of Educational Sciences, Tallinn University \\ ${ }^{b}$ School of Natural Sciences and Health, Tallinn University
}

\section{Summary}

According to the self-determination theory, the social environment can support personal motivation by satisfying a person's need for autonomy, competence and relatedness, the need to feel as an informed agent of one's actions who is able to cope with any situation, and as someone who is connected to others (Ryan \& Deci, 2000, 2002). In the classroom the teacher bears a significant role in creating a supportive social environment and, therefore, the teaching, organising and communicating behaviours of the teacher have an effect on the engagement of students (Jang et al., 2010; Reeve, 2009). Student engagement, being a multidimensional structure comprises of three inter-twined components: behavioural, cognitive and emotional engagement (Reeve \& Lee, 2014). Students who are engaged in classroom activities are committed and ready to put an effort into succeeding, they are actively participating in lessons and show positive emotions (interest, enthusiasm and optimism). Earlier studies have demonstrated the positive effect of teachers' autonomy supportive behaviours (using interesting and relevant teaching methods, offering challenges of optimal difficulty, and explicating important learning aims) on student engagement (Jang et al., 2010). Structured lessons, on the other hand, help create learning environments where learners are met with clear expectations, as well as offered guidance and feedback supporting the learning process. In other words, the structure enhances the students' will to act, whereas autonomy support enables the willingness to act to be self-determined and co-ordinated by the student's own internal means (Reeve, 2002).

In this article we focus on the association between teachers' instructional practices and students' engagement in learning. More specifically, we

1 School of Educational Sciences, Tallinn University, Uus-Sadama 5, 10120 Tallinn, Estonia; katrinpv@tlu.ee 
aim to analyse the associations between student engagement and teachers' behaviour that support autonomy and structuring. Based on earlier studies we assumed that autonomy support and structure would both be predictors of student engagement (Jang et al., 2010). We were also interested in analysing the differences between students' subjective appraisals of their engagement in classroom activities in the first and the third stages of basic school i.e. in the 2nd and 7th grade, as well as between genders. Based on previous research we expected girls to report higher levels of engagement than boys (Rimm-Kaufman et al., 2015).

In order to test these hypotheses we carried out classroom observations and asked the students to fill in questionnaires. We used a total of 41 different classroom observations in grade 2 (19 different teachers) and 50 observations in grade 7 (41 different teachers). Every lesson was observed by two independent observers using observation forms. The observation forms included the assessment of autonomy support and structuring behaviours, both on three aspects and using bipolar statements (Jang et al., 2010). Each bipolar statement was assessed on a 7 point Likert scale. The engagement was assessed on the basis of self-report instruments by 260 second graders (134 boys) and 207 seventh graders (100 boys). The students gave their assessments to four questions concerning their engagement at the end of each observed lesson (Fredricks et al., 2004; Jang et al., 2010). Descriptive analyses were carried out with SPSS 18.0. The two-level regression model was estimated with MPlus 6.0 (Muthén \& Muthén, 1998-2010).

On the basis of the observed lessons it can be concluded that 2 nd and 7 th grade teachers offer their students medium levels of autonomy and structure. At the same time second graders feel significantly more engaged than seventh graders in lesson activities, achieving significantly higher scores in all engagement dimensions. The engagement of second grade students can partly be positively influenced by class-teachers' higher mean level autonomy support and structuring behaviours compared to seventh grade teachers. At the same time the instructional practices of teachers varied notably, especially for autonomy support. When analysing the effect of the two components of instructional practices on students' engagement, it was shown that the support given by teachers to autonomy lead to students' mean level effort expenditure in the 2 nd grade and students' mean level enjoyment of the in the 7 th grade classes. Teacher's structuring activities had an effect only in the 7 th grade with students in more structured lessons being more attentive and exerting more effort.

As with teachers' instructional practices, there was also significant variation in students' engagement within classes and, therefore, we can assume 
that besides autonomy support, students' motivation and active engagement are also affected by students' individual characteristics that bear no direct associations with the classroom social environment. The positive correlation between the two components of instructional practices was expected as both are based on the learner-centred view of teaching, supporting student autonomy on the one hand and offering clear guidance and constructive feedback on the other (Sierens et al., 2009).

Assessing gender differences in students' assessments to their engagement confirmed our hypothesis. In the 2 nd grade girls were more engaged compared to the boys: they reported higher levels of attentiveness, higher effort and also more enjoyment of the lessons. In the 7 th grade the girls assessed themselves as more attentive and more engaged than boys. The results can be compared to similar international studies where girls tend to show higher levels of engagement than boys (Lietaert et al., 2014; Marks, 2000; Rimm-Kaufman et al., 2015). At the same time no gender differences can be found in school enjoyment in the 7 th grade. This component of enjoyment is also the lowest in the 2 nd as well as the 7 th grade.

To sum up, it can be stated that although 2 nd and 7 th grade students are all in all attentive and engaged in the lessons, their enjoyment of lessons is below average. Based on that, we recommend that in order to create autonomy supportive classrooms that could enhance students' motivation and engagement, more attention should be paid to the analysis and development of the quality of teachers' instructional practices during teacher training and in-service courses.

Keywords: self-determination theory, teacher instructional practices, autonomy and structure, student engagement 